University of Baltimore Law ScholarWorks@University of Baltimore School of Law

$12-29-2002$

\title{
Domestic Terror (The Sniper Suspect's Divorce Records Show Patterns of Power and Control and Missed Opportunities by the System to Intervene.)
}

Jane C. Murphy

University of Baltimore School of Law, jmurphy@ubalt.edu

Follow this and additional works at: http://scholarworks.law.ubalt.edu/all_fac

Part of the Criminal Law Commons, Family Law Commons, and the Law and Gender Commons

\section{Recommended Citation}

Domestic Terror, The Baltimore Sun, Perspective Section, December 29, 2002

This News Article is brought to you for free and open access by the Faculty Scholarship at ScholarWorks@University of Baltimore School of Law. It has been accepted for inclusion in All Faculty Scholarship by an authorized administrator of ScholarWorks@University of Baltimore School of Law. For more information, please contact snolan@ubalt.edu. 
Home $\rightarrow$ Collections $\rightarrow$ Domestic Violence

Related Articles
Help for battered women
May 12, 1992
Spouse beaters targeted
January 22, 1994
Domestic violence costs everyone
October 19, 1997
Focus on Domestic Violence
July 17,1994

\section{Find More Stories About}

Domestic Violence

Muhammad

Battered Women

\section{Domestic terror}

The sniper suspect's divorce records show patterns of power and control and missed opportunities by the system to intervene.

\begin{tabular}{ccc} 
Recommend $\sqrt{0}$ & \\
\hline 0 & $\bullet \vdots$ & 0 \\
\hline Tweet & $\bullet$ & $8+1$ \\
\hline
\end{tabular}

December 29, 2002 | By Jane C. Murphy | Jane C. Murphy,SPECIAL TO THE SUN

OVER THE PAST few months, we have learned much about the violent, troubled life of sniper suspect John Allen Muhammad. Whether or not he pulled the trigger - some recent reports have pointed to his 17 -year-old companion Lee Boyd Malvo as the main shooter - there is no doubt in the minds of domestic-violence experts that this adult is responsible for these deaths.

While many pundits conclude that we will never know what motivated the sniper suspect, to domestic violence experts his is an all-too-familiar story of a man whose relationships with the women and children - possibly including Malvo - in his life fit the power-and-control dynamic so common to batterers.

It is a story that includes regular contact with the legal system as Muhammad's marriages dissolved and issues about his children came before the courts, showing that authorities had the opportunity to intervene and perhaps prevent these multiple deaths and injuries.

First, understand the central role domestic violence played in this case and the potential for widespread violence in every abusive relationship. While no single type of batterer or one type of abuse defines domestic violence, researchers have developed patterns of behavior common in abusive relationships.

Power and control, rather than physical injury, is at the center of the battering relationship. A series of tactics - use of children, humiliation, display of weapons - draw their power from the threat of violence. The control intensifies when women attempt to separate from their abusive partners, in a phenomenon known as "separation assault." Battered women are at greatest risk when leaving a violent relationship.

An examination of Muhammad's relationships reveals behavior consistent with the batterer's profile. According to newspaper accounts, his divorce from his first wife, Carol Williams, was "bitter." Lindbergh, their adult son, describes his father as "a very good manipulator" who if "you let him inside your head, he will take control."

However, it's the details of his relationship with his second wife, Mildred Muhammad, and their children that resonate clearly with those who have counseled battered women. In several published interviews, she described the violence, threats and verbal assaults used to control her. Muhammad belittled her, knowing how to "push her buttons," telling her she was "not good enough ... not a good Muslim ... not a good mother." He accused her of having affairs and reported these allegations to their mosque. Typical of "separation assault," the control tactics escalated after she filed for divorce and, later in a request for restraining order alleging that her husband abused her, tapped her telephone and threatened to kill her.

The order was granted. Ten days later, John Muhammad took the couple's children. Failing to control his wife, Muhammad sought to control the children. In another series of hearings, the wife obtained custody and no visitation rights were awarded John Muhammad. He responded: "You are not going to raise my children. You have become my enemy, and as my enemy, I will kill you."

Mildred Muhammad was left with no option but to flee her home with her children. But John Muhammad neither gave up nor made changes that would have permitted him to resume a relationship with his children. He followed her to Maryland and, according to neighbors and relatives, began to stalk her by parking near her home and targeting places like Michaels craft stores and Home Depot, where she might shop. She speculated that the shooting spree that followed was calculated to terrorize her and provide an elaborate cover for her death.

John Muhammad was before Louisiana or Washington state courts at least a half-dozen times in cases involving family conflicts. How effective was the system's response? The Washington courts did some things right, such as granting a restraining order and denying Muhammad visitation. But could more have been done? Progress has been made in the legal system's response to domestic violence. But it still fails too many families, and court appearances are rarely opportunities for healthy intervention.

Some suggest that the effectiveness of reforms is limited because of our failure to understand the unique character of domestic violence. The traditional adversarial system's goals might not make sense for victims less interested in punishing past conduct than preventing future violence, protecting their children and obtaining treatment for a violent partner. Under such provocative labels as "therapeutic," "restorative" or "preventive" jurisprudence, scholars have proposed new approaches to respond to domestic violence. But the solution might be simpler than that. It might just boil down to understanding the importance of family cases and the profound costs of not paying adequate attention to them.

$1|2|$ Next 
Home $\rightarrow$ Collections $\rightarrow$ Domestic Violence

\begin{tabular}{l} 
Related Articles \\
Help for battered women \\
May 12, 1992 \\
Spouse beaters targeted \\
January 22, 1994 \\
Domestic violence costs everyone \\
October 19, 1997 \\
Focus on Domestic Violence \\
July 17,1994 \\
\hline
\end{tabular}

\section{Find More Stories About}

Domestic Violence

Muhammad

Battered Women

(Page 2 of 2)

\section{Domestic terror}

The sniper suspect's divorce records show patterns of power and control and missed opportunities by the system to intervene.

\begin{tabular}{|c|c|c|}
\hline Recom & $\{0$ & \\
\hline 0 & • : & 0 \\
\hline Tweet & $\bullet ?$ & $8+1$ \\
\hline
\end{tabular}

Some of the lack of attention is about money. In Maryland, family law cases make up 46 percent of the caseload in the circuit courts, more than all other civil cases combined and almost twice the number of criminal cases. But resources for handling family cases are inadequate.

Some new funding came when family divisions were established in 1998 in the state's largest jurisdictions. But resources are still spread too thin to offer troubled families services they need when they are in court.

In 2000 and last year, Robert M. Bell, chief judge of the Maryland Court of Appeals, sought funding for new judges to supplement or create new family divisions in the courts. Both times he was turned down.

Resources are only part of the problem. Lawyers often fail to give family-law cases the attention they deserve. John Mills, Muhammad's lawyer, is quoted as saying his client's divorce was "ordinary," but it is unclear whether he understood domestic violence. Few divorces are ordinary, and this wasn't one.

Judges also are part of the problem. Some avoid family-law cases, leaving them to new and inexperienced judges. Judicial selection favors prosecutors over experienced family lawyers. It's time potential judges learned that commitment to family law is a qualification for the job. Judges can play a significant role in changing behavior and mobilizing resources on behalf of families who come before them. Strong language from the bench, referral to treatment, monitoring and enforcing the restraining order, including the firearms provision, might have changed events in Muhammad's life.

Some of the components necessary to serve families are beginning to be developed in our court system - mental health and substance abuse evaluations, supervised visitation centers, parental skills classes and other services. These resources might have made a difference in Muhammad's divorce cases.

Providing troubled families with the best we can offer is long overdue. Shifting priorities to families before violence erupts will protect us all. Perhaps that is the only meaningful lesson that can be taken from this tragedy.

Jane C. Murphy is a professor and director of clinical education at the University of Baltimore School of Law.

Prev $|1| 2$

\section{See Also}

1. Causes of ADHD Disorder

2. Early Signs of Alzheimer's

3. Top 5 Wrinkle Creams

4. Top 2015 Luxury Cars

MORE:

Kelly eyes just Ravens Agent: Marchibroda only coach for ex-Bill

Man accused of aiding brother in murder plotFREDERICK..

What killed the famous tenor?

Six decades of scientific genius

Parted twins' future bright Surgery: After a virtual reality rehearsal, a Johns Hopkins doctor leads the successful separation of Zambian joined-at-the-head twins.

Murder as child's play
Advertisement

\section{Reverse Mortgage Calculator}

6. New Luxury Cars

7. Little Black Dresses

8. Top Home Security Systems 